\title{
Interleukin 11 Measurement
}

National Cancer Institute

\section{Source}

National Cancer Institute. Interleukin 11 Measurement. NCI Thesaurus. Code C74807.

The determination of the amount of interleukin 11 present in a sample. 